ELISABETTA GARGANI ${ }^{\text {a }}$ - CLAUDIA BENVENUTI ${ }^{\text {a }}$ LEONARDO MARIANELLI ${ }^{\text {a }}$ - PIO FEDERICO

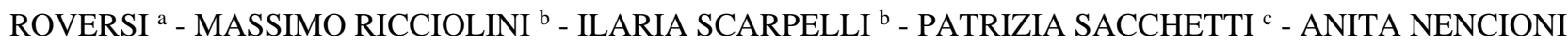
c,d. - DOMENICO RIZZO ${ }^{\text {b }}$ - AGOSTINO STRANGI ${ }^{\text {a }}$ - IMMACOLATA IOVINELLA ${ }^{\text {a }}$ - ILARIA CUTINO ${ }^{a}$

\title{
A FIVE-YEAR SURVEY IN TUSCANY (ITALY) AND DETECTION OF XYLELLA FASTIDIOSA SUBSPECIES MULTIPLEX IN POTENTIAL INSECT VECTORS, COLLECTED IN MONTE ARGENTARIO
}

\author{
${ }^{a}$ Council for Agricultural Research and Economics (CREA), Research Centre for Plant Protection and Certifi- \\ cation, Via Lanciola 12/a, 50125 Firenze (Italy). \\ ${ }^{b}$ Tuscany Regional Plant Health Service (RPS-Tuscany) Via Manzoni, 16 - 50121 Firenze (Italy). \\ ${ }^{c}$ University of Florence, Department of Agriculture, Food, Environment and Forestry (DAGRI) Via Maragliano, \\ 77, 50144 Firenze (Italy). \\ ${ }^{d}$ Institute of Bioeconomy (IBE), National Research Council of Italy, Research Campus of Florence - Via Ma- \\ donna del Piano, 10, 50019 Sesto Fiorentino (Firenze, Italy). \\ Corresponding Author: Elisabetta Gargani; email: elisabetta.gargani@crea.gov.it
}

Gargani E., Benvenuti C., Marianelli L., Roversi P.F., Ricciolini M., Scarpelli I., Sacchetti P., Nencioni A., Rizzo D., Strangi A., Iovinella I., Cutino I. - A five-year survey in Tuscany (Italy) and detection of Xylella fastidiosa subspecies multiplex in potential insect vectors, collected in Monte Argentario.

The vector-borne bacterium Xylella fastidiosa (Wells and Raju) causes several serious diseases to plants. Recently, different subspecies of $X$. fastidiosa were reported in some European countries. The risk of the bacterium's spread on the entire European territory is very high; therefore, it has been added into the priority pest list (2019/1702/EU Regulation). The main purposes of this work were to verify the presence of potential vectors in areas at a high risk of introduction in Tuscany and to ascertain the presence of $X$. fastidiosa in these insect vectors. Over 4,000 Auchenorrhyncha were collected and analysed from 2015 to 2019. Among the xylem sap-feeder putative vectors, most of the insects collected belonged to the family Aphrophoridae, but also many species of leafhopper were identified. Overall, in Tuscany four species were the most represented: Philaenus spumarius (L.), Cicadella viridis (L.), Synophropsis lauri (Horvath) and Neophilaenus campestris (Fallen). In 2018 an outbreak of $X$. fastidiosa subsp. multiplex was reported in Monte Argentario (Grosseto province, Tuscany). In 2019 X. fastidiosa subspecies multiplex ST 87 was detected in seven $P$. spumarius and three $N$. campestris collected from the infected area.

KEY Words: Mediterranean maquis, Multilocus Sequence Typing, Philaenus spumarius, Neophilaenus campestris

\section{INTRODUCTION}

The Gram-negative bacterium Xylella fastidiosa (Wells and Raju) is a vector-transmitted plant pathogen associated with over than 595 plant species, 275 genera and 85 families (EFSA, 2020a), including 40 crops highly valuable for human nutrition (CORNARA et al., 2019), species of ornamental/environmental importance and landscape plants. According to the International Society of Plant Pathology Committee on the Taxonomy of Plant Pathogenic Bacteria (ISPP-CTPPB) $X$. fastidiosa is currently divided only in fastidiosa, multiplex and pauca subspecies as valid, with the inclusion of sandyi and morus in the fastidiosa subspecies (DENANCÈ et al., 2019). The bacterium is well known in the world as the cause of Pierce's disease (PD) of grapevine, Citrus Variegated Chlorosis (CVC), Almond Leaf Scorch (ALS), and Oleander Leaf Scorch (OLS) (JANSE and OBRADOVIC, 2010). During 2013, the subsp. pauca (SAPONARI et al., 2013) was detected for the first time in Europe, in Apulia (Italy) in association with "Olive Quick Decline Syndrome" (OQDS), causing severe losses of olive trees. Consequently, on 13 February 2014, the European Commission approved the Implementing Decision 2014/87/EU related to the measures to prevent the spread of $X$. fastidiosa in the European Union.
In Italy, the National Plant Health Service programmed a surveillance plan by an emergency action aimed to rapidly detect $X$. fastidios $a$ according to the Italian Ministry decision "DLgs n. 789, 19 June 2015". An early detection is essential to optimise the chances of eradication as detailed in the $X$. fastidiosa EU Pest Risk Assessment (EFSA, 2019) and subsequent updates (EU Reg 2020/1201). From the first European introduction in Apulia, X. fastidiosa was detected in France, Spain, Portugal, while in Germany, after a single detection, it was declared eradicated (EPPO, 2019). X. fastidiosa is considered as "transient under eradication" in European areas, except for the Apulia region, Corsica and Balearic Islands, where the status is "present with a restricted distribution" (EPPO, 2020). Recently, the bacterium was also reported in Israel (EPPO, 2019). One of the most important characteristics of $X$. fastidiosa is its transmission from plant to plant by xylem-sap sucking insects (REDAK et al., 2004); this is the main dissemination method of dispersion of the bacterium; therefore a list of potential insect vectors and their distribution should be defined in each target area for $X$. fastidiosa emergence (MIZELL et al., 2008).

The relation between the bacterium $X$. fastidiosa and its vectors, belonging to the group of xylem-sap feeders of the order Hemiptera, suborder Cicadomorpha, was 
highlighted in America, where the bacterium is endemic (REDAK et al., 2004). In Europe, the most abundant putative vectors recognised are spittlebugs (EFSA, 2015), which belong to the superfamily Cercopoidea (froghoppers and spittlebugs), whereas only the subfamily Cicadellinae (sharpshooters) seems to be involved (CORNARA et al., 2019) among the family Cicadellidae. A metadata of faunistic surveys performed in different European habitats and in olive groves in Brazil has been reported in a database that provides information about $\mathrm{xy}$ lem-sap feeder species in Europe (XF-Actors, 2020). To date, out of the 119 potential vectors that feed on xylemsap (CHAUVEL et al., 2015; DI SERIO et al., 2019), the meadow spittlebug Philaenus spumarius (Linnaeus, 1758) has been identified as the most effective vector of $X$. fastidiosa subsp. pauca in Southern Italy (SAPONARI et al., 2014; CORNARA et al., 2017a). Furthermore, recent studies (CAVALIERI et al., 2018; CAVALIERI et al., 2019) highlighted that the spittlebugs Neophilaenus campestris Fallen (1805) and Philaenus italosignus Drosopoulos \& Remane (2000) are also able to transmit $X$. fastidiosa to olive and other plants under experimental conditions. In the other European regions, evidences about putative vectors are limited although infected specimens of $P$. spumarius were detected in Corsica (CRUAUD et al., 2018) and South of France (CUNTY et al., 2020), and both $P$. spumarius and $N$. campestris were found positive for the bacterium in Spain (HEALTH et al., 2018). Therefore, improvement of knowledge on the biology, ecology and population density of the putative vectors' species is fundamental to a better understanding of the epidemiology of the associated disease and its spread to different areas (EUPHRESCO, 2019).

At the end of 2018 in the Monte Argentario area (Grosseto province, Southern Tuscany, Central Italy), some samples of Spartium junceum L. and other plants of the Mediterranean maquis were found infected by $X$. fastidiosa subsp. multiplex (MARCHI et al., 2018). After the first detection, the territory of the Monte Argentario municipality was included in a demarcated area. Thus, in 2019 , more extended surveys were performed in this area to detail the spread of the pathogen and to better understand the role of putative insect vectors.

The objectives of the present work were: i) to investigate the presence of the potential insect vectors in high risk areas for bacterium introduction in Tuscany; ii) to verify the presence of $X$. fastidiosa in potential vectors in such areas at a high risk of introduction and in the demarcated zone of Tuscany; iii) to identify the bacterium subspecies from positive insects collected in Monte Argentario (demarcated area) in 2019.

\section{MATERIALS AND METHODS}

\section{SAMPLING OF INSECTS IN TUSCANY}

The collection sites, during the five-year survey (2015-2019) in Tuscany, were established by European and Italian Decrees and Regulations. A different number of sampling sites, identified as at high risk for the bacterium introduction, was surveyed each year through the entire territory of Tuscany: 207 sites in 2015, 219 in 2016,
263 in 2017, 277 in 2018 and 174 in 2019. The monitoring sites were:

a) areas with symptoms of declining host plants;

b) main connecting routes where specified plants are used as road trees;

c) areas where production and trade activities are performed concerning the host plants (olive crops, Prunus orchards, vineyards, forestry, etc.), nursery areas and garden centres;

d) other areas with a high risk of introduction (weeds, areas around ports, airports, inter-ports, rest areas in streets and highways, tourist areas, areas around mills producing olive oil or areas around other agriculture productions, areas around nurseries, natural environments, and urban areas).

The surveys were performed from June to November, when the adults of the main potential vectors are used to occur. In each sampling site, a maximum number of five specimens was collected in 15 minutes inspections using a sweep net (with at least ten swept per site) as part of a qualitative sampling. Single specimens were gathered using a micro-aspirator and stored in $1.5 \mathrm{ml}$ microtubes in $96 \%$ ethanol and uniquely catalogued in the field until laboratory analyses.

The sampling was focused on insects belonging to the superfamily Cercopoidea, mainly Philaenus spumarius and Neophilaenus campestris according to EFSA (EFSA, 2015) because all sharpshooter and spittlebug species can be vectors of $X$. fastidiosa (ALMEIDA et al., 2005; PURCELL, 1990). However, some phloem-feeders were also considered in this survey (e.g., leafhoppers of the family Cicadellidae or planthoppers as Issidae and Cixidae) since they can occasionally get in contact with the xylem sap (POMPON et al., 2011; ElBEAINO et al., 2014).

In the laboratory, all the specimens collected were taxonomically identified and analysed for the presence of $X$. fastidiosa. All the Auchenorrhyncha adults were identified using the most common taxonomical keys (BIEDERMANN and NIEDRINGHAUS, 2009, DROSOPOULOS and REMANE, 2000, HolzINGER et al., 2003; KUNZ et al., 2011; WILSON et al., 2015). Taxonomic characterization was performed in two steps: (1) the specimen was first observed under a stereomicroscope with a specific focus on external morphology and (2) after biomolecular analysis (when only insect heads were used), male specimens were dissected and clarified (by boiling gently in water-diluted $10 \% \mathrm{KOH}$ for 5-7 minutes) to prepare male genitalia in a non-permanent slide (Hoyer liquid) for optical microscopy.

\section{SAMPLING OF INSECTS IN MONTE ARGENTARIO (DEMAR- CATED AREA)}

After the detection of $X$. fastidiosa subspecies multiplex strain ST87 on Spartium junceum in Monte Argentario, the entire area was declared demarcated (MARCHI $e t$ al., 2018). The monitoring and sampling of the plants in the delimited area was performed by Tuscany Regional Plant Health Service (RPS-Tuscany), which also collected and analysed insect specimens randomly found.

The Monte Argentario promontory (approximately $60 \mathrm{~km}^{2}$ ) is considered a "fossil island" that was connected to Tuscany mainland by sand deposits in recent times, 
forming two internal lagoons inside three cordons of dunes named "tomboli". The climate is typically Mediterranean with a mild winter and a warm and arid summer (ARRIGONI and Di TOMMASO, 1997). The presence of the sea, the lagoons, the ridges and the hills clearly affect the climate; thus, there are several local climate conditions.

Anthropic disturbances, including recurrent fires, and land use for farming, grazing, creation of parks and gardens around villas and the partial reforestations of Monte Argentario have generated a complex mosaic of plant communities at different successional stages with more or less distance from climax (VICIANI et al., 2018).

In 2019 a specific study was carried out to assess the presence of the known potential vectors of the bacterium and of other Auchenorrhyncha to better understand the prevalence of the different species and to detect $X$. fastidios a positive insects. The study was carried out from April to November into six sampling sites (about $1,500 \mathrm{~m}^{2}$ each): three included in the infected zone (Quadrivio, Cacciarella, Poggio Pertuso) and three in the buffer zone (Stadio, Capo d'Uomo, Cannelle) (Table 1).

In the six monitored areas, no specific local management was applied to control $X$. fastidiosa vectors. For each site, four 20x2 m transects, arranged in a cross, were sampled from early May to late November every two weeks. Climatic data for the year 2019 were acquired from the LaMMA Consortium (http://www.lamma.rete. toscana.it), such as minimum and maximum of daily temperature as well as rainfall.

Each transect was divided in $5 \mathrm{~m}$ sub-transects where insects were collected from the herbaceous layer with five sweep-netting each, for both qualitative and quantitative sampling. In addition, a total of five shrubs and/or trees (Olea europaea, Spartium junceum, Rhamnus alaternus, Pistacia lentiscus, Quercus ilex, Q. suber, Pinus pinea, Prunus amygdalus, Calicotome spp., Cistus spp. etc.) were monitored in each transect performing ten swept- on the canopy. If no shrub/tree occurred in the transect, a variable number (maximum five) of nearby tree plants were surveyed.

The taxonomic identification of collected insects was accomplished as previously described.

\section{STATISTICAL ANALYSIS}

Data collected during 2019 Monte Argentario survey were statistically analysed. After applying the test of Kolmogorov-Smirnov to verify if the observed distribution deviates significantly from the theoretical Gaussian distribution, we obtained the assumption of normality of our data, so an ANOVA comparison test was used to determine the significant differences between pairs of mean values and a post hoc Tukey test $(\mathrm{P}=0.05)$ was also performed. Only for the species that were present during all the seasons ANOVA analysis was performed and used to compare the independent variables (seasons, monitoring areas and sampling dates) with the dependent variable, namely the number of insect species collected. All the statistical analysis (ANOVA and post hoc comparison) were computed with the program SPSS (RRID:SCR_002865).

\section{MOLECULAR METHODS}

Field collected insects stored in ethanol $96 \%$ were analysed to detect $X$. fastidiosa via molecular tests. DNA extraction was performed using only the head of the insects, including the foregut and avoiding contaminations from the remainder of the body (PURCELL et al. 2014). Individuals belonging to the same species were pooled from two to ten insects for DNA extraction (EFSA, 2019; EPPO 2019).

DNA extractions from single or pooled heads were performed using the commercial kit DNeasy Blood \& Tissue Kits (Qiagen) following the manufacturer's protocol with some minor modifications.

Molecular detection of $X$. fastidiosa was performed following selected amplification protocols described in EPPO (2019). The first test was conducted using a qPCR protocol described in HARPER, et al. (2010) (Appendix 5 of EPPO, 2019).

To confirm the presence of $X$. fastidiosa, samples with positive qPCR results were subject to the Loop Mediated Isothermal Amplication (LAMP), a second test based on a sequence located in a different region of the gene coding for the 16S rRNA-processing RimM protein. Amplification conditions were the same as described in the Appendix 10 of EPPO (2019). For both tests the DNA of $X$. fastidiosa subspecies fastidiosa (ST2) received from the RPS Tuscany was used as positive amplification control (PAC). X. fastidiosa was considered detected in the corresponding sample only when positive results were obtained for both qPCR and LAMP.

Positive samples were characterized based on a multilocus sequence typing (MLST) analysis (YUAN et al., 2010) of seven housekeeping genes to determine the subspecies and strain. Amplification reactions were performed in a total volume of $50.0 \mu \mathrm{l}$ containing $25.0 \mu \mathrm{l} \mathrm{HS}$ DreamTaq Master Mix 2X, $13.0 \mu \mathrm{ldd}_{2} \mathrm{O}, 0.6 \mu \mathrm{M}$ each primer, $0.3 \mu \mathrm{g} / \mu \mathrm{l} \mathrm{BSA}$ and $2.0 \mu \mathrm{l}$ DNA. Primers sequences and PCR thermal program were described in Appendix 14 of EPPO (2019). Amplicons of good quality and at the expected size were sequenced and compared with those obtained from the DNA of $X$. fastidiosa multiplex isolated from Spartium junceum collected in the infected zone. Strain identification was performed using the database available at http://pubmlst.org/xfastidiosa/ (JOLLEY et al., 2004).

Insects sample, collected by RPS-Tuscany, were analysed using the following methods: genomic DNA was extracted from single specimens (whole body) using the CTAB extraction method reported by LI et al. (2008) with slight modifications. The amplifiability of DNA extracted from the insects was tested in a qPCR reaction using a dual-labelled probe targeting a highly conserved region of the 18S rDNA (IoOs et al., 2009). Molecular detection of $X$. fastidiosa was performed using the qPCR protocol described in HARPER et al. (2010). For an independent confirmation, the positive samples were analysed using the qPCR reaction described by OUYANG et al. (2013) (Appendix 4, EPPO, 2019). Positive samples of $X$. fastidiosa for both qPCR and LAMP were also characterized with MLST (YUAN et al., 2010) as described above. 
Table 1 - Details of the six collecting sites in the Monte Argentario: Site name, Cartesian coordinates, Altitude, Exposure, Type of monitored site, Type of zone, Vegetational characterization, Infection-based status and Infected plant presence.

\begin{tabular}{|c|c|c|c|c|c|c|}
\hline & Cannelle & Capo d'Uomo & Stadio & Quadrivio & Cacciarella & $\begin{array}{l}\text { Poggio } \\
\text { Pertuso }\end{array}$ \\
\hline $\begin{array}{l}\text { Cartesian co- } \\
\text { ordinates }\end{array}$ & $\begin{array}{l}42.3863330 \mathrm{~N} \\
11.1452100 \mathrm{E}\end{array}$ & $\begin{array}{l}42.4006520 \mathrm{~N} \\
11.1126679 \mathrm{E}\end{array}$ & $\begin{array}{l}42,4293100 \mathrm{~N} \\
11.1791820 \mathrm{E} \\
\end{array}$ & $\begin{array}{l}42.4331524 \mathrm{~N} \\
11.1271099 \mathrm{E}\end{array}$ & $\begin{array}{l}42.4376252 \mathrm{~N} \\
11.1079763 \mathrm{E} \\
\end{array}$ & $\begin{array}{l}42.4046535 \mathrm{~N} \\
11.2013578 \mathrm{E} \\
\end{array}$ \\
\hline $\begin{array}{l}\text { Altitude } \\
\text { (m a.s.1.) }\end{array}$ & 93 & 349 & 3 & 108 & 183 & 8 \\
\hline Exposure & North West & South East & North & West & North & South \\
\hline $\begin{array}{l}\text { Monitoring } \\
\text { sites }\end{array}$ & ${ }^{2}$ Rest areas & ${ }^{2}$ Rest areas & ${ }^{2}$ Rest areas & ${ }^{2}$ Rest areas & Olive crop & $\begin{array}{l}\text { Natural envi- } \\
\text { ronment }\end{array}$ \\
\hline $\begin{array}{l}\text { Demarcated } \\
\text { zones }\end{array}$ & Buffer zone & Buffer zone & Buffer zone & Infected zone & Infected zone & Infected zone \\
\hline $\begin{array}{l}\text { Vegetation } \\
\text { type }\end{array}$ & $\begin{array}{l}\text { Mediterranean } \\
\text { maquis }\end{array}$ & Garrigue & $\begin{array}{l}\text { Polyphytic } \\
\text { meadow with } \\
\text { sporadic } \\
\text { Quercus } \\
\text { suber trees }\end{array}$ & $\begin{array}{l}\text { Thermo-Mediter- } \\
\text { ranean scrub for- } \\
\text { mations }\end{array}$ & $\begin{array}{l}\text { Olive grove } \\
\text { with weeds } \\
\text { cover } \\
\text { (Asteraceae, } \\
\text { Asphodelus } \\
\text { sp., Foenicu- } \\
\text { lum sp., Or- } \\
\text { chis italica) }\end{array}$ & Garrigue \\
\hline $\begin{array}{l}\text { Infected } \\
\text { plants close } \\
\text { to transects } \\
\text { (number) }\end{array}$ & none & none & none & $\begin{array}{l}\text { Rhamnus } \\
\text { alaternus (4) } \\
\text { Cistus sp. (1) } \\
\text { Prunus } \\
\text { amygdalus (1) } \\
\text { Calicotome sp. (4) } \\
\text { Spartium junceum } \\
\text { (1) }\end{array}$ & $\begin{array}{l}\text { Rhamnus } \\
\text { alaternus (4) } \\
\text { Spartium } \\
\text { junceum (2) } \\
\text { Calicotome } \\
\text { sp. (1) }\end{array}$ & $\begin{array}{l}\text { Ficus carica } \\
\text { (1) } \\
\text { Cistus } \\
\text { monspeliensis } \\
(2)\end{array}$ \\
\hline $\begin{array}{l}\text { Infected } \\
\text { plants 500- } \\
1000 \mathrm{~m} \\
\text { around } \\
\text { transects } \\
\text { (number) }^{1}\end{array}$ & $\begin{array}{l}\text { Rhamnus } \\
\text { alaternus (8) } \\
\text { Prunus } \\
\text { amygdalus (1) } \\
\text { Rosmarinus of- } \\
\text { ficinalis (1) } \\
\text { Calicotome sp. } \\
(2) \\
\text { Cistus sp. (2) } \\
\text { Cytisus sp. (1) } \\
\text { Spartium } \\
\text { junceum (1) }\end{array}$ & none & none & $\begin{array}{l}\text { Lavandula den- } \\
\text { tata (1) } \\
\text { Rhamnus } \\
\text { alaternus (3) } \\
\text { Spartium junceum } \\
\text { (2) } \\
\text { Cistus sp. (1) } \\
\text { Helichrisum } \\
\text { italicum (1) }\end{array}$ & $\begin{array}{l}\text { Rhamnus } \\
\text { alaternus (4) } \\
\text { Calicotome } \\
\text { sp. (1) } \\
\text { Prunus } \\
\text { amygdalus } \\
\text { (1) }\end{array}$ & $\begin{array}{l}\text { Rhamnus } \\
\text { alaternus (1) }\end{array}$ \\
\hline
\end{tabular}

${ }^{1}$ Infected plants detected at the end of 2019

${ }^{2}$ Rest areas in street and highways, tourist areas, areas around mills producing olive oil or areas around other agriculture productions, areas around nurseries

\section{RESULTS}

\section{SAMPLING OF INSECTS IN TUSCANY}

During the five-year survey in Tuscany, more than 4,000 Auchenorrhyncha specimens were collected, identified and analysed. No X. fastidiosa-positive insects were found. The total number of insects gathered per year, grouped by taxa, are reported in Table 2. In some cases, it was not possible to define the species given the absence of males among the collected specimens, unsolved taxonomic disputes, or due to the destructive manipulation for biomolecular analysis, so that some samples have been characterized only at the genus or family/subfamily level (Table 2).

Overall, insects belonging to 8 families were identifi- 
Table 2 - Auchenorrhyncha collected during the survey period (2015-2019) in Tuscany: number of specimens and their taxonomic identification.

\begin{tabular}{|c|c|c|c|c|c|c|}
\hline \multicolumn{7}{|c|}{ Number of specimens } \\
\hline Taxa & 2015 & 2016 & 2017 & 2018 & 2019 & Total \\
\hline \multicolumn{7}{|l|}{ Aphrophoridae } \\
\hline Lepyronia coleoptrata (L.) & 67 & 6 & 0 & 2 & 8 & 83 \\
\hline Aphrophora alni (Fallen) & 19 & 8 & 0 & 13 & 1 & 41 \\
\hline Neophilaenus spp. & 4 & 5 & 13 & 18 & 8 & 48 \\
\hline Neophilaenus campestris (Fallen) & 26 & 34 & 70 & 189 & 163 & 482 \\
\hline Philaenus spumarius (L.) & 146 & 364 & 225 & 467 & 276 & 1478 \\
\hline \multicolumn{7}{|l|}{ Cercopidae } \\
\hline Cercopis vulnerata Rossi & 2 & 1 & 0 & 0 & 0 & 3 \\
\hline \multicolumn{7}{|l|}{ Cicadellidae } \\
\hline Agallia spp. & 26 & 1 & 12 & 6 & 0 & 45 \\
\hline Anoplotettix spp. & 1 & 0 & 0 & 0 & 0 & 1 \\
\hline Artianus sp. & 0 & 0 & 15 & 21 & 0 & 36 \\
\hline Cicadella viridis (L.) & 330 & 199 & 114 & 63 & 15 & 721 \\
\hline Fieberiella florii (Stal) & 8 & 0 & 10 & 9 & 0 & 27 \\
\hline $\begin{array}{l}\text { Phlogotettix cyclops (Mulsant \& } \\
\text { Rey) }\end{array}$ & 3 & 2 & 0 & 1 & 0 & 6 \\
\hline Synophropsis laurii (Horvath) & 57 & 22 & 217 & 217 & 0 & 513 \\
\hline Scaphoideus titanus Ball & 1 & 0 & 0 & 1 & 0 & 2 \\
\hline Subfamily Deltocephalinae & 116 & 2 & 320 & 6 & 0 & 444 \\
\hline \multicolumn{7}{|l|}{ Membracidae } \\
\hline $\begin{array}{l}\text { Stictocephala bisonia Kopp \& } \\
\text { Yonke }\end{array}$ & 2 & 0 & 0 & 0 & 0 & 2 \\
\hline \multicolumn{7}{|l|}{ Cixidae } \\
\hline Hyalesthes spp. & 10 & 2 & 0 & 0 & 0 & 12 \\
\hline \multicolumn{7}{|l|}{ Dictyopharidae } \\
\hline Dictyophara sp. & 1 & 0 & 0 & 0 & 1 & 2 \\
\hline \multicolumn{7}{|l|}{ Flatidae } \\
\hline Metcalfa pruinosa (Say) & 3 & 0 & 0 & 0 & 0 & 3 \\
\hline \multicolumn{7}{|l|}{ Issidae } \\
\hline Agalmatium spp. & 31 & 3 & 3 & 20 & 0 & 57 \\
\hline Total per year & 853 & 649 & 999 & 1033 & 472 & 4006 \\
\hline
\end{tabular}

ed. The most represented family was Aphrophoridae with 2,132 individuals collected and belonging to the species P. spumarius, $N$. campestris, Lepyronia coleoptrata and Aphrophora alni.

Philaenus spumarius, the main target of the monitoring, due to the fact that it is known as the most efficient vector of $X$. fastidiosa subsp. pauca in Apulia (SAPONARI et al., 2014; CORNARA et al., 2017a), was the most abundant collected species (1,478 individuals). Apart from $P$. spumarius, Cicadella viridis L. (n. 721), Synophropsis lauri (Horvath) (n. 513) and N. campestris (n. 482) were gathered in large quantities.

The regional distribution of the two main potential vectors, $P$. spumarius and $N$. campestris, has been repre- sented in the map in Fig. I. Philaenus spumarius was the main species in the Northern provinces as Prato, Pistoia, and Lucca, while along the coast, both species exhibit a similar presence.

SAMPLING OF INSECTS IN MONTE ARGENTARIO (DEMARCATED AREA)

From April to late November 2019, a total of 662 Auchenorrhyncha were collected in the demarcated area. In Table 3 is reported the number of specimens captured per taxa, per season and per vegetation type. The trend of climatic data in 2019 was characterized by a drought summer (June-July) and quite mild temperatures during winter ( $\mathrm{T} \max 32.6{ }^{\circ} \mathrm{C}$ on June $29^{\text {th }}$; T min $1.02^{\circ} \mathrm{C}$ 


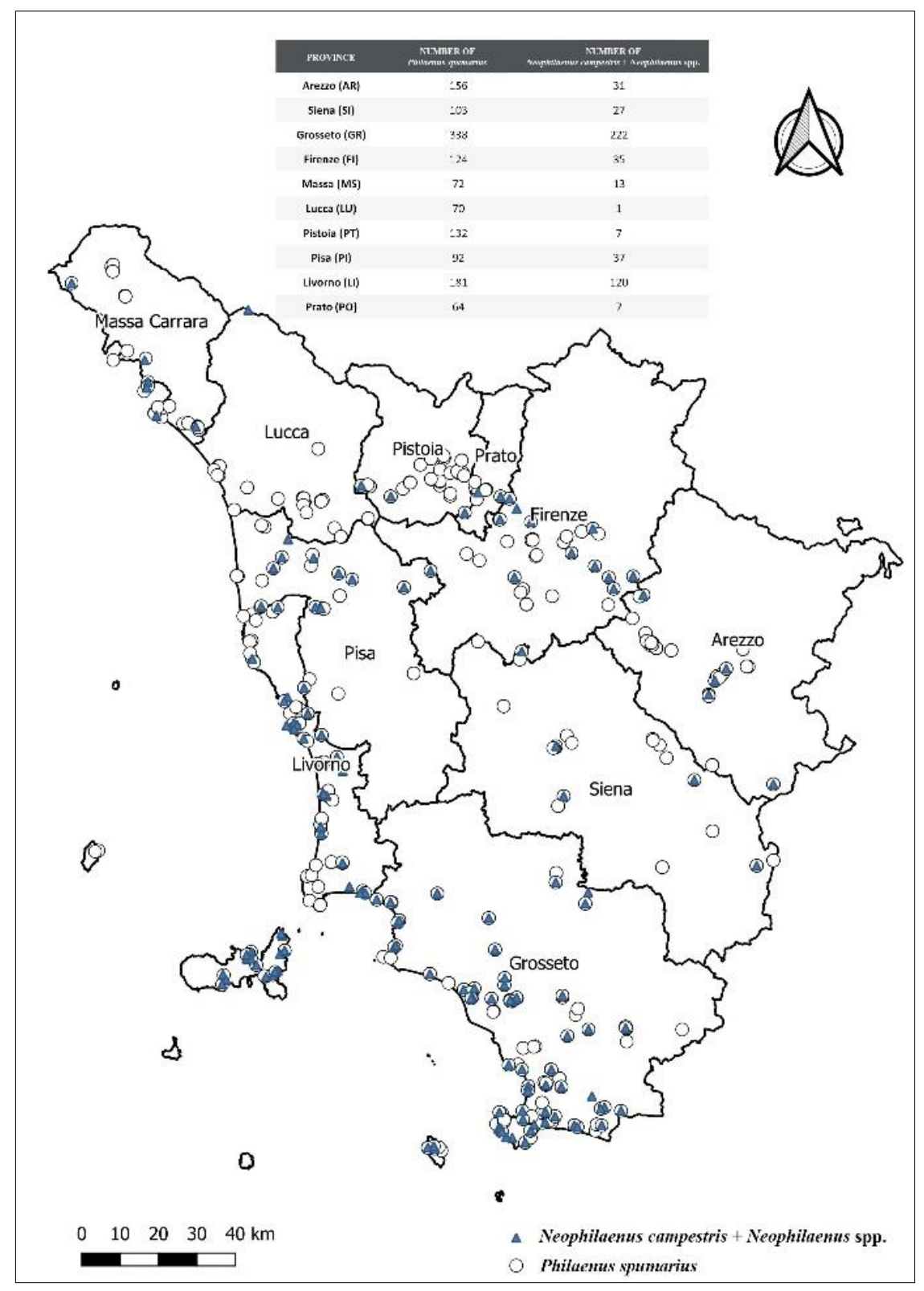

Fig. I - Monitored areas where Philaenus spumarius, Neophilaenus spp. and N. campestris were swept-caught in Tuscany during the 5-year survey; the number of specimens for each province is reported in the table inside Fig. I.

on January $5^{\text {th }}$ ) (See supplementary material Fig. IS: https://www.redia.it/images/stories/pdf2021/Gargani_et_al_Redia_104_Fig_1_Supplementary.pdf), confirming the usual tendency of this area.

Overall, Aphrophoridae was the most represented family $(58 \%)$ followed by Issidae $(22 \%)$ and Cicadellidae (18\%). The spittlebugs $P$. spumarius (n. 258) and $N$. campestris (n. 89) were the main species for number of collected individuals. Synophropsis lauri (n. 22) and Anoplotettix fuscovenosus (Ferrari) (n. 23), which were primarily caught in Cacciarella and Poggio Pertuso, were the most collected species among the family Cicadellidae, while Agalmatium flavescens (Olivier) (n. 66) and Issus coleoptratus (Fabricius) (n. 31) were the most abundant species among Issidae (Table 3).

Regarding the presence of the species on different type of vegetation (Table 3 ), it can be pointed out that $P$. spumarius was captured especially on herbaceous plants, during spring and fall, while in summer, when however, the captures were reduced, the greatest numbers were on trees. On the contrary, N. campestris and Neophilaeus sp. were almost exclusively caught on herbaceous plants (Table 3).

Significant differences were found considering a comparison among the different taxa in the different seasons with regard to Neophilaenus sp. $(\mathrm{F}=3.849$; $\mathrm{df}=2$; $\mathrm{p}=0.024)$, Euscelis sp. $(\mathrm{F}=4.004 ; \mathrm{df}=2 ; \mathrm{p}=0.021)$ and $S$. laurii $(\mathrm{F}=4.662 ; \mathrm{df}=2 ; \mathrm{p}=0.011)$, whereas no significant differences were detected for $P$. spumarius, Agalmatium sp. and Issus coleoptratus (Fig. II).

Even if the comparison among average of the insects captured and the different sampling sites gave no significant difference, it is clear that Cacciarella followed by Poggio Pertuso, both of which are in the infected area, and Stadio, which is in the buffer zone (Fig. III), were the sites where we collected the higher number of specimens. 
Table 3 - Species, genus and families collected in 2019 into the six areas of Monte Argentario per season and per vegetation type.

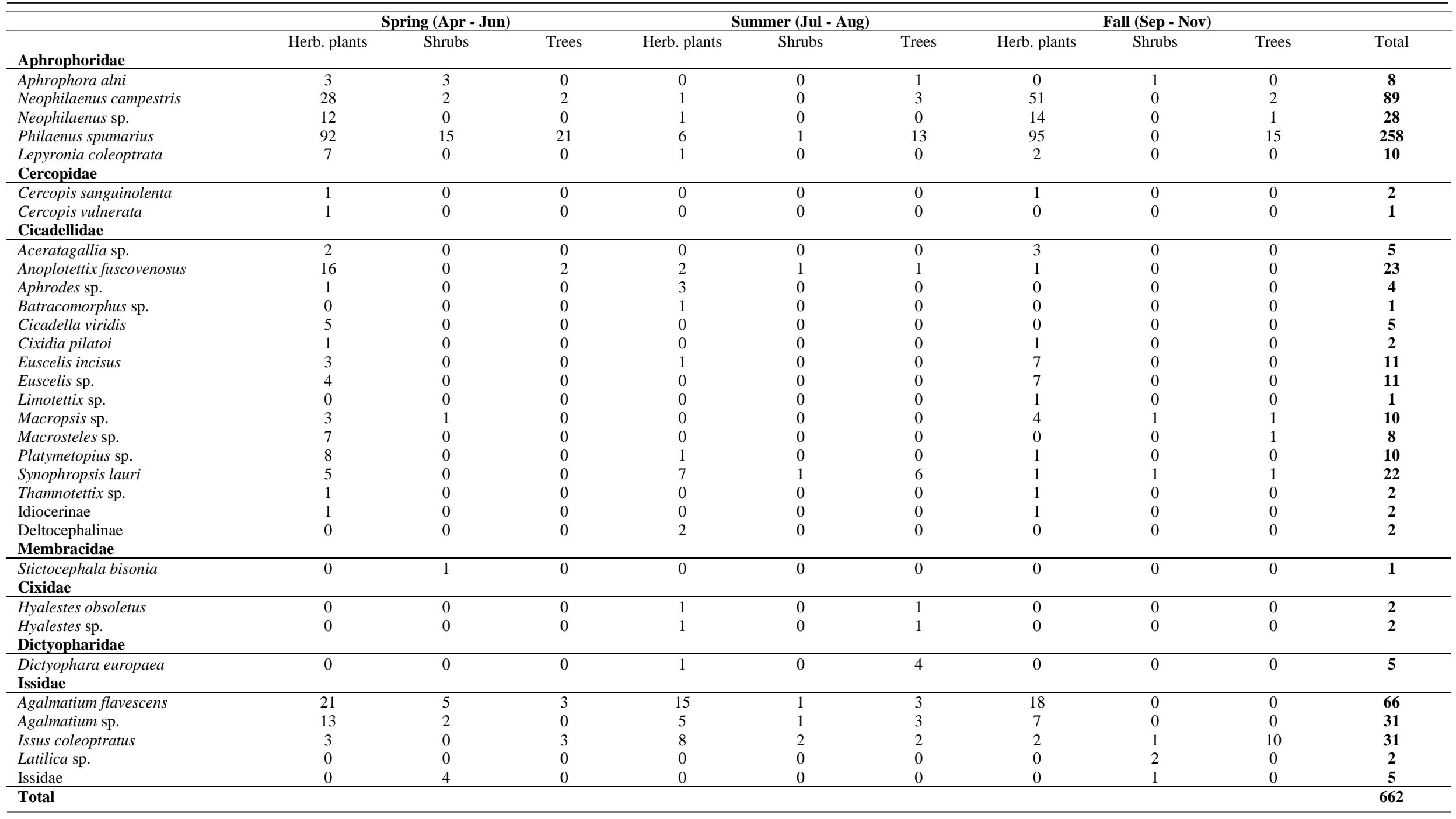




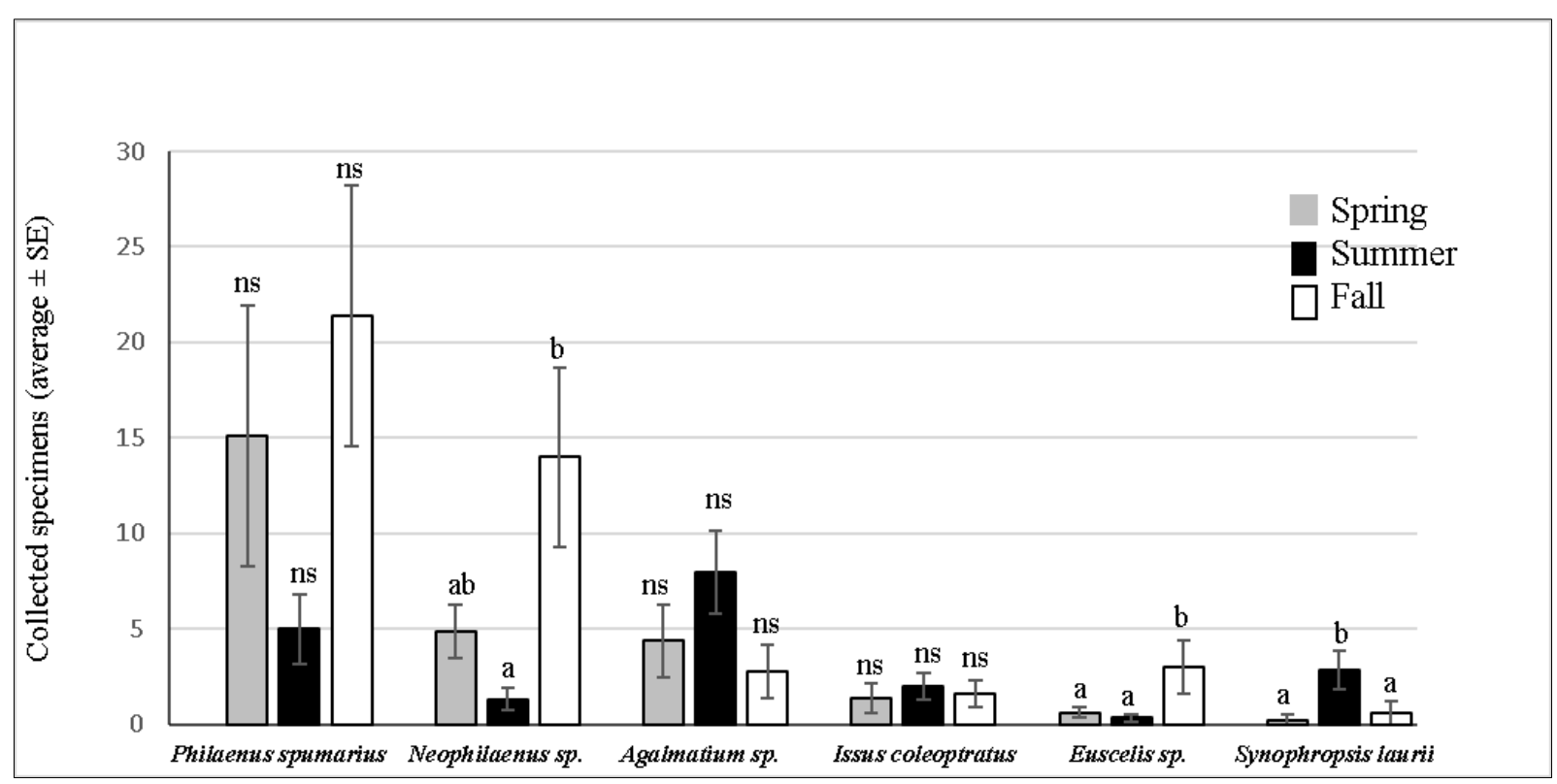

Fig. II - Averages and standard errors of seasonally caught insects by taxa in the Monte Argentario area. Tuckey test: the mean difference is significant at 0.05 level ( $\mathrm{ns}=$ not statistically significant; groups with the same letter $-\mathrm{a}$, b- are not significantly different).

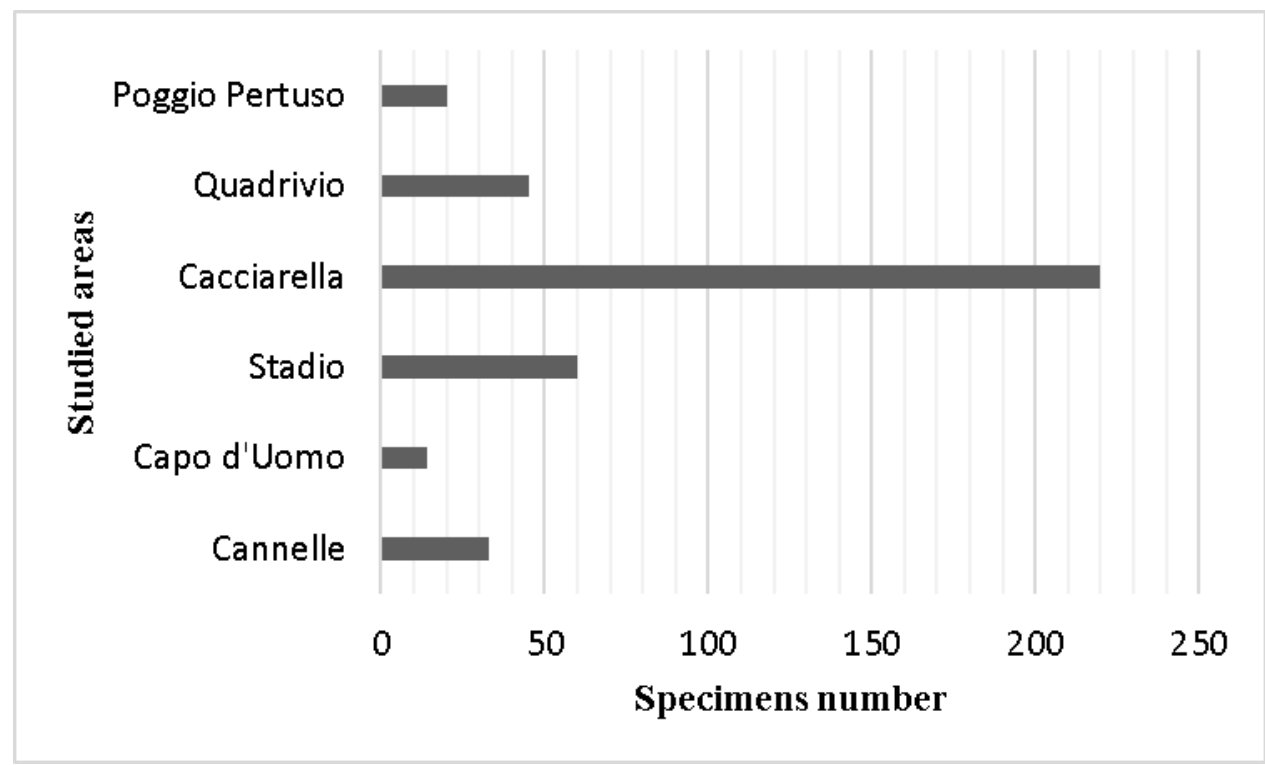

Fig. III - Bar chart reporting the number of potential vectors of Xylella fastidiosa (Aphrophoridae, Cercopidae and Cicadellinae) collected in the different Monte Argentario sites.

A smaller number of insects was collected, instead, in Quadrivio (infected area) and in the two other buffer area sites (Capo d'Uomo and Cannelle).

The average number of the species collected compared with the date of sampling, gave no significant results.

\section{MOLECULAR ANALYSES}

Molecular analyses carried out on over the 4,000 Au- chenorrhyncha collected during the general monitoring in Tuscany, from 2015 to 2019, gave only negative results. In the last year (2019), the 662 insects collected from infected and buffer areas of Monte Argentario were also analysed. According to the diagnostic procedures (positive amplification with qPCR and LAMP) (Fig. IV) eight positive samples, including six made by pools of $P$. spumarius, and two made by pools of $N$. campestris were obtained. 
Two additional samples, one of $P$. spumarius and one of $N$. campestris were found positive, according to the analyses conducted by the RPS-Tuscany laboratory.

To independently confirm the presence of $X$. fastidiosa in the 10 samples and to determine the subspecies and strain, MLST analysis was conducted (Table 4). We obtained a complete MLST profile only for 4 samples. For the remaining 6 samples, ST was not assignable due to failure in the sequencing of some alleles. Since the only sequence type found in Tuscany was the ST87 both for plants and insects, we hypothesise that the attribution of ST is the same for all samples with incomplete MLST profiles. No alleles were sequenced for sample 276 (Table 4) because its DNA was completely used for optimisation of PCR amplifications.

\section{DISCUSSION}

In the five-year survey, over 4,000 Auchenorrhyncha including putative vectors of $X$. fastidiosa were collected and analysed in Tuscany. The most abundant species gathered in the current study were $P$. spumarius and $N$. campestris. These two species were recognised by different authors (SAPONARI et al., 2014; CORNARA et al., 2017a; CORNARA et al., 2017b; EFSA, 2018) as the main vectors of $X$. fastidiosa subsp. pauca in South Italy and were also the main targets of our sampling. Other spittlebugs, L. coleoptrata and A. alni, were also collected in Tuscany in the surveyed areas at risk of introduction for $X$. fastidiosa. The numbers of Aphrophoridae, as well as other Auchenorrhyncha collected during the five-year sampling are consistent with the results previously reported for Tuscany (MAZZONI, 2005) and Mediterranean countries (CORNARA et al., 2019; EFSA, 2019; MORENTE et al., 2018; ANTONATOS et al., 2020). Philaenus italosignus, recently recorded in the Maremma Regional Park, located in Grosseto province (PANZAVOLTA et al., 2019) and reported as potential vector of $X$. fastidiosa subspecies pauca (CAVALIERI et al., 2019), was not detected during our monitoring. As a matter of fact, no $P$. italosignus was found in the surveyed areas, even in the Monte Argentario area and in Cacciarella site, where some plants of Asphodelus sp., the principal host of the preimaginal stages of the species, occurred.

The two most abundant species $P$. spumarius and $N$. campestris exhibit a wide distribution over the Tuscany region. Even if vector survey is considered by EFSA (2020b) less efficient than plant survey, the occurrence of the two main putative vectors in most of the Tuscan areas at risk of potential introduction of $X$. fastidiosa, is an important result that can be used to organize the planning of preventive actions to avoid the spread of the bacterium in the region (MARKHEISER et al., 2020). An active surveillance of the territory is fundamental to an early outbreak detection (CRUAD et al., 2018), as occurred at the end of 2018 in the Monte Argentario area (REASER et al., 2020).

Data on the epidemiology of $X$. fastidiosa in Europe are lacking (WHITE et al., 2020) except for the Apulia situation and for the subsp. pauca.

In other countries, only faunistic researches were performed (ALBRE and GIBERNAU, 2019) and to date, in Tuscany, the epidemiology of the bacterium is unclear. Our survey confirms the occurrence of the principal putative vectors of $X$. fastidiosa, in the demarcated area of Monte Argentario, during the period April- November with a higher presence in spring and fall on herbaceous plants. Philaenus spumarius and $N$. campestris are known to show a migratory behaviour (CORNARA et al., 2018; BODINO et al., 2020), and move from herbaceous plants towards woody species during summer months. According to this, our results display that spittlebugs were collected mainly from trees and shrubs, such as Quercus ilex, Q. suber, Olea europaea and Pinus pinea, during the period July-August. Regarding N. campestris and related species, the tendency to exploit coniferous plants as summer refuges (MAZZONI, 2005; BODINO et al., 2020; LAGO et al., 2020) could explain the significant difference in the number of collected specimens between summer and fall. In fact, these plants were often too hight or unreachable for the hand sweeping net, so they were only sporadically sampled, may causing an underestimate of Neophilaenus sp. populations abundance. On the contrary, in fall, the sampling of the herbaceous layer allows to assess the large presence of adult spittlebugs that were mating and ovipositing.

In the Monte Argentario area, the number of infected insects detected in 2019 (10 out of $662 ; 1.5 \%$ ) was not consistent with the number of infected plants ( 275 out of 7,$109 ; 3.8 \%$ ) (official data reported by RPS-Tuscany in Brussels). In fact, molecular detection of X. fastidiosa in insects sampled in areas where infected plants occurred, frequently gave negative results. For instance, in the infected zone Quadrivio where 19 plants (Table 1) were infected, $X$. fastidiosa was not detected in any of the collected insects. On the contrary, in the Cacciarella site with 13 infected plants, 5 positive insects were detected. This last site was particularly suitable for spittlebugs, in fact, Cacciarella area is characterized by an olive grove surrounded by Mediterranean scrub, scattered fruit trees and a clearing covered by herbaceous plants. Nevertheless, it is important to underline that no positive olive tree was found there and that $P$. spumarius and $N$. campestris were almost completely absent during central summer months on olive tree canopies. Instead, in the same period, numerous specimens of $S$. lauri, Cicadellidae Deltocephalinae were present on the olive trees. These data are consistent with those reported for Apulian olive groves, where $P$. spumarius was poorly present in olive canopies due to movements towards other woody hosts in summer (BODINO et al., 2019). Moreover, P. spumarius and $N$. campestris have been collected sporadically from the plant species recorded as positive to $X$. fastidiosa subsp. multiplex while these trees and shrubs hosted other Auchenorrhyncha such as Agalmatium sp., Issus coleoptratus and Euscelis sp.

The positive insects from Monte Argentario were 
Table 4 - List of positive samples, insect species, number of pooled insects, MLST allele number with the attribution of the Sequence Type (ST).

\begin{tabular}{|c|c|c|c|c|c|c|c|c|c|c|c|}
\hline & & & & \multicolumn{7}{|c|}{ Allele number } & \\
\hline $\begin{array}{l}\text { Sample } \\
\text { number }\end{array}$ & Name & Species & pool & CysG & GltT & HolC & LeuA & MalF & $\begin{array}{l}\text { Nuo } \\
\text { L }\end{array}$ & PetC & ST \\
\hline 106 & $\begin{array}{l}\text { Poggio } \\
\text { Pertuso }\end{array}$ & P. spumarius & 4 & 3 & 3 & 3 & 5 & 5 & 21 & 3 & 87 \\
\hline 144 & Cacciarella & P. spumarius & 9 & 3 & 3 & 3 & - & 5 & 21 & 3 & n.a. \\
\hline 147 & Cacciarella & N. campestris & 10 & 3 & 3 & 3 & - & 5 & 21 & 3 & n.a. \\
\hline 153 & Cacciarella & P. spumarius & 6 & 3 & 3 & - & - & 5 & - & 3 & n.a. \\
\hline 163 & Cacciarella & P. spumarius & 7 & 3 & 3 & 3 & 5 & 5 & 21 & 3 & 87 \\
\hline 164 & Cacciarella & N. campestris & 4 & 3 & 3 & 3 & - & 5 & 21 & 3 & n.a. \\
\hline 225 & $\begin{array}{l}\text { Monte } \\
\text { Argentario- } \\
\text { buffer zone } \\
42,26351 \mathrm{~N}, \\
11,0654 \mathrm{E}\end{array}$ & P. spumarius & 5 & 3 & 3 & 3 & 5 & 5 & 21 & 3 & 87 \\
\hline 276 & $\begin{array}{l}\text { Monte } \\
\text { Argentario- } \\
\text { buffer zone } \\
42,38601 \mathrm{~N}, \\
11,20259 \mathrm{E}\end{array}$ & P. spumarius & 2 & - & - & - & - & - & - & - & n.a. \\
\hline SFR1 & Buffer zone & P. spumarius & 1 & & & & & & & & \\
\hline SFR2 & Buffer zone & N. campestris & 1 & 3 & 3 & 3 & 5 & 5 & 21 & 3 & 87 \\
\hline
\end{tabular}

n.a.: not assignable

all captured between late September and the beginning of November when the spittlebug population was more abundant according to other authors (CORNARA et al., 2019), and the insects might have fed on multiple host plants, increasing the chances of being infected (EFSA, 2019).

This hypothesis is suggested also by other authors (CRUAUD et al., 2018; BODINO et al., 2019) who found $P$. spumarius positive for $X$. fastidiosa more frequently in September and October. For this reason, could be more advisable to survey potential insect vectors in these periods.

While the presence of $X$. fastidiosa subsp. multiplex ST87 in Monte Argentario area was previously assessed and characterized by MARCHI et al. (2018) in several plant species, in the present work the $X$. fastidiosa sequence type was univocally determined in 4 samples out of the 10 positive samples (Table 4).

The extensive survey performed on plants across the Tuscany region prompted delimiting an outbreak 


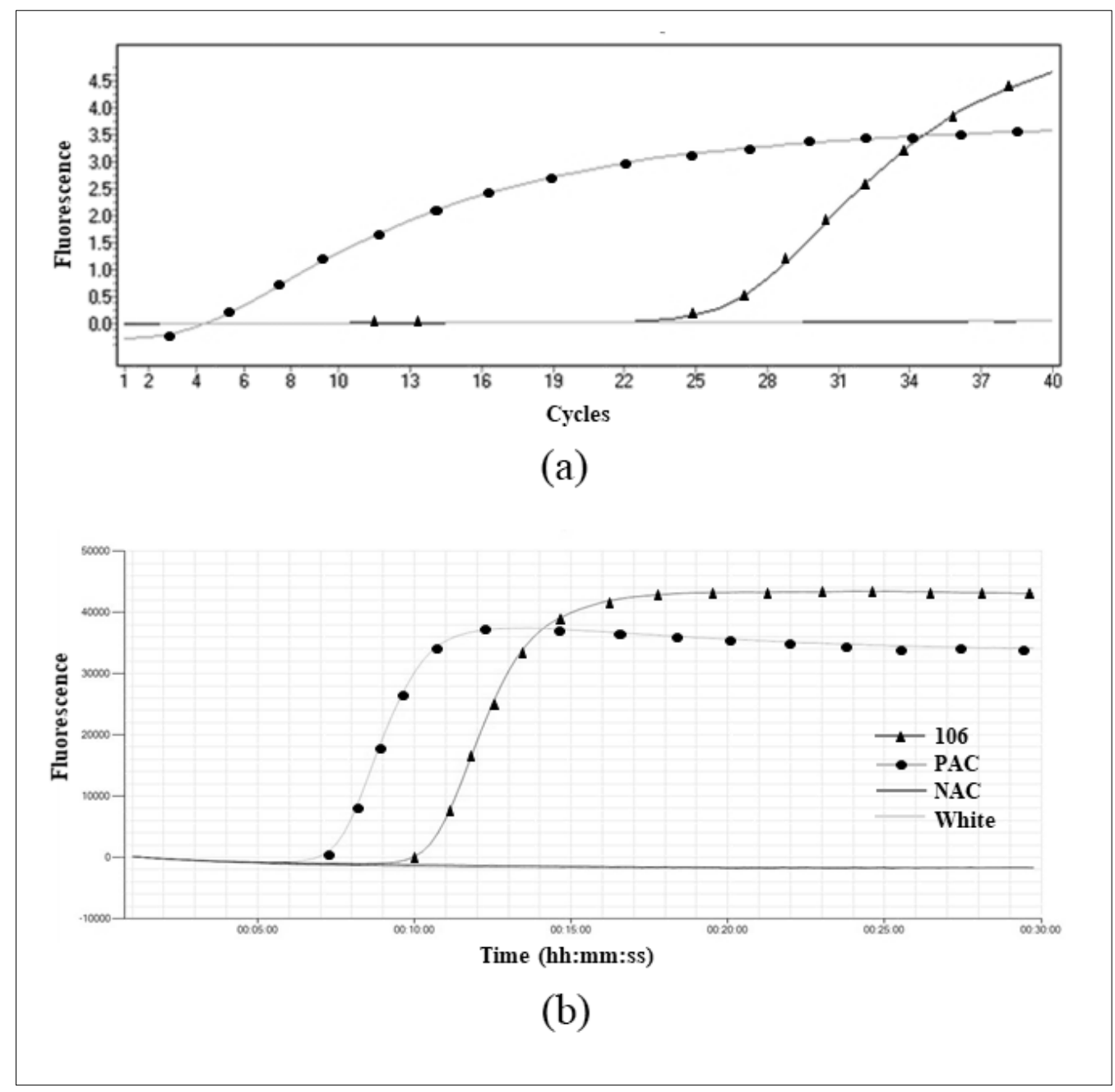

Fig. IV - (a) qPCR amplification curve of sample 106 (line with triangles) compared to the curve of the DNA of $X$. fastidiosa fastidiosa (ST2) used as positive amplification control (PAC) (line with dots), the negative amplification control (NAC) (dark grey) and the amplification control without DNA (light grey). (b) LAMP amplification curve of sample 106 (line with triangles) compared to the curve of the DNA of $X$. fastidiosa fastidiosa (ST2) used as positive amplification control (PAC) (line with dots), the negative amplification control (NAC) (dark grey) and the amplification control without DNA (light grey).

area in Monte Argentario, and these results were also confirmed in the insect survey.

However, given that the number of positive insects found in the demarcated area were much lower with respect to positive plants detected, we hypothesised that the plant monitoring for $X$. fastidiosa detection is more efficient to identify new outbreaks, according to EFSA (2020b).

Our study suggests that the putative vector survey is one first step to understand the epidemiology of the infection. The epidemiology of $X$. fastidios $a$ and its subspecies is multifaceted and complex, and every pathosystem requires specific knowledge. For the Tuscan outbreak, the most efficient vector still remains unclear.

The occurrence of $X$. fastidiosa subsp. multiplex in Monte Argentario represents a challenge since this area is one of the most important for the conservation of Mediterranean maquis and its biodiversity within Tuscany. Since the environment of Monte Argentario is completely different from the areas of Apulia (South Italy) where the most important epidemiological studies in Italy on $X$. fastidiosa and its environmental interactions have been conducted. Further studies are in progress to better clarify the vector population dynamics and ecology, the host preference, and the capacity of acquisition as well as the efficacy of transmission of the bacterium.

\section{REFERENCES}

Albre J., GiBernau M., 2019 - Diversity and temporal variations of the Hemiptera Auchenorrhyncha fauna in the Ajaccio region (France, Corsica). - Ann. Soc. Entomol. Fr., NS: 497-508.

AlMEIDA R.P., BlUA M.J., LOPES J.R., PURCELL A.H., 2005 - Vector transmission of Xylella fastidiosa: applying fundamental knowledge to generate disease management strategies. - Ann. Entomol. Soc. Am., 98: 775-786. 
Antonatos S., PAPAChristos D.P., KAPANTAIDAKI D.E., LYTRA I.C., VARIKOU K., EVANGELOU V.I., MILONAS P., 2020 - Presence of Cicadomorpha in olive orchards of Greece with special reference to Xylella fastidiosa vectors. - J. Appl. Entomol., 144: 1-11.

ARRIGONI P.V., DI TOMMASO P.L. 1997 - La vegetazione del Monte Argentario (Toscana meridionale). - Parlatorea, 2: 5-38.

BIEDERMANN R., NIEDRINGHAUs R., 2009 - The plant-and leafhoppers of Germany: identification key to all species. - WABV Fründ Germany, pp.410.

Bodino N., CAVAlieri V., DOngIOVAnni C., Altamura G., SAladini M.A., SAPONARI M., Bosco D., 2019 - Transmission characteristics of Xylella fastidiosa subsp. pauca (ST53) by Philaenus spumarius and Cicadella viridis. In: Proceedings of 2nd European Conference on Xylella fastidiosa, 29-30 October 2019, Ajaccio, France. Book of abstract. Zenodo.

Bodino N., Cavalieri V., Dongiovanni C., Saladini M.A., Simonetto A., Volani S., Plazio E., Altamura G., Tauro D., Gilioli G., Bosco D., 2020 Spittlebugs of Mediterranean olive groves: Host-plant exploitation throughout the year. - Insects, 11: 130.

Cavalieri V., Altamura G., Fumarola G., Di Carolo M., Saponari M., Cornara D., Bosco D., DONGIOVANNI C., 2019 - Transmission of Xylella fastidiosa subspecies pauca sequence type 53 by different insect species. - Insects, 10: 324.

Cavalieri V., Dongiovanni C., Tauro D., Altamura G., Di CAROlO M., Fumarola G., SAPONARI M., BOSCO D., 2018 - Transmission of the codiro strain of Xylella fastidiosa by different insect species. In: Book of Abstracts -XI European Congress of Entomology, 2-7 July Naples, Italy.

Chauvel G., CRuAud A., Legendre B., Germain J.F., RASPLUS J.Y., 2015 - Rapport de mission d'expertise sur Xylella fastidiosa en Corse. - Rapport définitif (2015-08-31), 139 pp.

CORNARA D., SAPONARI M., ZEILINGER A.R., DE Stradis A., Boscia D., Loconsole G., Bosco D., Martelli G.P., Almeida R.P., Porcelli F., 2017a Spittlebugs as vectors of Xylella fastidiosa in olive orchards in Italy. - J. Pest. Sci., 90: 521-530.

Cornara D., Cavalieri V., Dongiovanni C., Altamura G., Palmisano F., Bosco D., Porcelli F., AlMEIDA R.P., SAPONARI M., 2017b. - Transmission of Xylella fastidiosa by naturally infected Philaenus spumarius (Hemiptera, Aphrophoridae) to different host plants. - J. App. Ent., 141: 80-87.

Cornara D., Bosco D., Fereres A., 2018 Philaenus spumarius: when an old acquaintance becomes a new threat to European agriculture. - Journal of pest science, $91: 957-972$.

CORNARA D., MORENTE M., MARKHEISER A., Bodino N., Tsai C.W., FERERES A., REDAK R.A., PERRING T.M., LOPES J.R.S., 2019 - An overview on the worldwide vectors of Xylella fastidiosa. - Entomol. Gen., 10: 157-181.

Cruaud A., Gonzalez A.A., Godefroid M., Nidelet S., StReito J.C., ThUILlieR J.M., Rossi J.P., SANTONI S., RASPLUS J.Y., 2018 - Using insects to detect, monitor and predict the distribution of Xylella fastidiosa: a case study in Corsica. - Sci. Rep., 8: 1-13.

CUNTy A., LEgENDRE B., DE JERPHANION P., JuteAu V., FORVEILlE A., GERMAIN J.F., RAMEL J.M., REYNAUd P., OliVIER V., POLIAKOFF F., 2020 - Xylella fastidiosa subspecies and sequence types detected in Philaenus spumarius and in infected plants in France share the same locations. - Plant Pathol., 69: 1798-1811.

DENANCÉ N., BRIAND M., GABORIEAU R., JACQUES M.A., 2019 - Identification of genetic relationships and subspecies signatures in Xylella fastidiosa. - BMC Genomics, 20: 239.

Di SERIO F., Bodino N., CAVAlieri V., Demichelis S., Di Carolo M., Dongiovanni C., Fumarola G., Gilioli G., Guerrieri E., Picciotti U., 2019 - Collection of data and information on biology and control of vectors of Xylella fastidiosa. - EFSA Supporting Publications, $102 \mathrm{pp}$.

Drosopoulos S., REMANE R., 2000 Biogeographic studies on the spittlebug Philaenus signatus Melichar, 1986 species group (Hemiptera: Aphrophoridae) with the description of two new allopatric species. - Ann. Soc. Entomol. Fr., 36: 269-277.

(EFSA). EUROPEAN FOOD SAFETY AUTHORITY, 2015 - Scientific Opinion on the risks to plant health posed by Xylella fastidiosa in the EU territory, with the identification and evaluation of risk reduction options. 13: 3989.

(EFSA). EUROPEAN FOOD SAFETY AUTHORITY, 2018 - Updated pest categorisation of Xylella fastidiosa. 16: 5357 .

(EFSA). EUROPEAN FoOd SAFETY AUTHORITY, 2019 - Pest survey card on Xylella fastidiosa. EN-1667.

(EFSA). EUROPEAN FOOD SAFETY AUTHORITY, 2020a - Update of the Xylella spp. host plant databasesystematic literature search up to 30 June 2019. 18: 6114.

(EFSA). EUROPEAN FOOD SAFETY AUTHORITY, 2020b - Guidelines for statistically sound and risk-based surveys of Xylella fastidiosa.

Elbeaino T., YASEen T., VAlENTINI F., BEN Moussa I.E., MAZZONI V., D'ONGHIA A.M., 2014. Identification of three potential insect vectors of Xylella fastidiosa in southern Italy. - Phytopathologia Mediterranea, 328-332.

(EPPO). EUROPEAN AND MEDITERRANEAN Plant Protection ORgANIZATION, 2020 - EPPO Global Database. https://gd.eppo.int/

(EPPO) EUROPEAN AND MEDITERRANEAN PLANT PROTECTION ORGANIZATION, 2019 - PM 7/24 (4) Diagnostic standard for Xylella fastidiosa. - EPPO Bulletin., 49: 175-227.

EUPHRESCO PROJECT, 2019 - Xylella fastidiosa and its insect vectors - Final report.

HARPER S., WARD L., Clover G., 2010 Development of LAMP and real-time PCR methods for the rapid detection of Xylella fastidiosa for quarantine and field applications (Erratum 2013). - Phytopathology, 100: 1282-1288.

Health E., Panel O.P., Jeger M., CafFier D., CANDREsse T., Chatzivassiliou E., DEHNEN-SCHMUTZ 
K., Gilioli G., Grégoire J.C., JaQues Miret J.A., MACLEOD A., NAVAJAS NAVARRO M., NIERE B., PARNEll S., PotTing R., RAfOSS T., Rossi V., UREK G., VAN BRUGGEN A., VAN DER WERF W., WEST J., WINTER S., Almeida R., Bosco D., Jacques M.A., LANDA B., PURCELl A., SAPONARI M., CZWIENCZEK E., DELBIANCO A., StAnCANElli G., BRAGARD C., 2018 - Updated pest categorisation of Xylella fastidiosa. - EFSA Journal 16.

Holzinger W., KAMMERLANDER I., NICKEL H., 2003 - The Auchenorrhyncha of Central Europe-Die Zikaden Mitteleuropas Fulgoromorpha, Cicadomorpha exc Cicadellidae. - Brill. Academic Publishers,Leiden Boston, 673 pp.

IOOS R., FOURRIER C., IANCU G., GORDON T.R., 2009 - Sensitive detection of Fusarium circinatum in pine seed by combining an enrichment procedure with a realtime polymerase chain reaction using dual-labeled probe chemistry. - Phytopathology, 99: 582-590.

JANSE J., OBRADOVIC A., 2010 - Xylella fastidiosa: its biology, diagnosis, control and risks. - J. Plant. Pathology, 92 (S1):35-48.

JOLLEY K.A., CHAN M.S., MAIDEN M.C., 2004 mlstdbNet-distributed multi-locus sequence typing (MLST) databases. - BMC Bioinformatics, 5: 1-8.

KUNZ G., NICKEL H., NIEDRINGHAUS R., 2011 Fotoatlas der Zikaden Deutschlands: photographic atlas of the planthoppers and leafhoppers of Germany. WABV Fründ, 293pp.

Lago C., Morente M., De las Heras-Bravo D., MARTY CAMPOY A., RodRIGUEZ-BALlESTER F., PlazA M., MoRENO A., FERERES A., 2020 - Dispersal ability of Neophilaenus campestris, a vector of Xylella fastidiosa, from olive groves to over-summering hosts. - bioRxiv 2020.03.17.995266,

doi:https://doi.org/10.1101/2020.03.17.995266.

LI R., Mock R., HuANG Q., ABAD J., HARTUNG J., KINARD G., 2008 - A reliable and inexpensive method of nucleic acid extraction for the PCR-based detection of diverse plant pathogens. - J. Virolog. Meth.,154: 48-55.

MARCHI G., RIZZO D., RANALDI F., GHELARDINI L., RicCIOLINI M., SCARPELli I., DROSERA L., EMANUELE G., CAPRETTI P., Surico G., 2018 - First detection of Xylella fastidiosa subsp. multiplex DNA in Tuscany (Italy). - Phytopathol. Mediterr., 57: 363-364.

MARKHEISER A., MAIXNER M., 2019 - Significance of xylem feeding Auchenorrhyncha in orchards and vineyards in Germany. In: Proceedings of European Conference on Xylella fastidiosa: finding answers to a global problem, Palma de Mallorca, Spain.13-17 November 2017. pp. 21.

MARKHEISER A., CORNARA D., FERERES A., MAIXNER M., 2020 - Analysis of vector behavior as a tool to predict Xylella fastidiosa patterns of spread. Entomol. Gen., 40 (1): 1-13.

Mizell R. F., ANDERSON P., TIPPING C., BRODBECK B., 2008 - Xylella fastidiosa diseases and their leafhopper vectors. - Dept. of Entomology and Nematology, Florida Cooperative Extension Service, University of Florida, USA.

Morente M., Cornara D., Plaza M., Durán J.M., Capiscol C., Trillo R., Ruiz M., RuZ C.,
SAnJuAn S., PEREIRA J.A., 2018 - Distribution and relative abundance of insect vectors of Xylella fastidiosa in olive groves of the Iberian Peninsula. - Insects, 9: 175192.

Ouyang P., ArIF M., Fletcher J., Melcher U., CORONA F.M.O., 2013 - Enhanced reliability and accuracy for field deployable bioforensic detection and discrimination of Xylella fastidiosa subsp. pauca, causal agent of citrus variegated chlorosis using Razor Ex technology and TaqMan quantitative PCR. - PloS ONE, 8 (11): 1-13.

Panzavolta T., Bracalini M., CROCI F., GHELARDini L., LUTI S., CAMPIGLI S., GOTI E., MARCHI R., TIBERI R., MARCHI G., 2019 - Philaenus italosignus $a$ potential vector of Xylella fastidiosa: occurrence of the spittlebug on olive trees in Tuscany (Italy). - Bull. Insectology, 72 (2): 317-320.

POMPON J., QUIRING D., GOYER C., GIORDANENGO P., PEL-LETIER Y., 2011. A phloem-sap feeder mixes phloem and xylem sap to regulate osmotic potential. Journal of Insect Physiology, 57: 1317-1322.

PURCELL A.H., 1990 - Homopteran transmission of xylem-inhabiting bacteria. In: Adv Dis Vector Res, Harris, K.F. - Ed. Springer: New York, USA, 6: 243-266.

Purcell A.H., Porcelli F., Cornara D., Bosco D., PICCIAU L., 2014 - Characteristics and identification of xylem-sap feeders. In: Proceedings of Workshop manual.

REDAK R.A., PURCELL A.H., LOPES J.R., BLUA M.J. MiZELL R.F., ANDERSEN P.C., 2004 - The biology of xylem fluid-feeding insect vectors of Xylella fastidiosa and their relation to disease epidemiology. - Annu. Rev. Entomol., 49: 243-270.

SAPONARi M., Boscia D., Nigro F., MARTElli G.P., 2013 - Identification of DNA sequences related to Xylella fastidiosa in oleander, almond and olive trees exhibiting leaf scorch symptoms in Apulia (Southern Italy). - J. Plant. Pathology, 95(3):659-668.

SAPONARI M., LOCONSOlE G., CORNARA D., Yokomi R.K., De Stradis A., Boscia D., Bosco D., MARTelli G.P., Krugner R., PORCElli F., 2014 Infectivity and transmission of Xylella fastidiosa by Philaenus spumarius (Hemiptera: Aphrophoridae) in Apulia, Italy. - J Econ. Entomol., 107: 1316-1319.

Viciani D., Dell'Olmo L., FogGi B., Ferretti G., LASTRUCCI L., GENNAI M., 2018 - Natura 2000 habitat of Mt. Argentario promontory (southern Tuscany, Italy). - Journal of Maps 14: 447-454.

White S., NAvas-Cortés J.A., Bullock J.M., BoscIA D., CHAPMAN D.S., 2020 - Estimating the epidemiology of emerging Xylella fastidiosa outbreaks in olives. - Plant Pathology, 69:1403-1413.

WILSON M., StEWART A., BIEDERMANN R., NICKEL H., NIEDRINGHAUS R., 2015 - The planthoppers and leafhoppers of Britain and Ireland: identification keys to all families and genera and all British and Irish species not recorded from Germany. - WABV Fründ: Scheeßel, Germany, 138 pp.

XF-ACTORS VECTOR WORKING GROUP, 2020 Survey data of xylem-feeding Auchenorrhyncha. doi:10.5281/zenodo.3775537. 
Yuan X., Morano L., Bromley R., SpringPeArson S., Stouthamer R., NunNeY L., 2010 Multilocus sequence typing of Xylella fastidiosa causing
Pierce's disease and oleander leaf scorch in the UnitedStates. - Phytopathology, 100: 601-611. 